\title{
What Has Ethiopia Got to Do with India? Reflections of the First German Lutheran Missionaries in India
}

\author{
Martin Tamcke
}

When the Protestant churches of Germany started their worldwide missionary work, neither Ethiopia nor India were considered a dark horse. Historical records on both countries were of great importance to German Protestant theologians since the beginning of the Reformation. ${ }^{1}$ Early historiography was the source of their knowledge about these countries and their respective local Orthodox churches. But their knowledge was by no means limited to the historiographical legacy. Even Martin Luther and Philipp Melanchthon had theological and religious discussions with monks from Ethiopia, a subject which Stanislau Paulau explored in his dissertation. ${ }^{2}$ There were numerous ways to gain knowledge about these countries and their churches. Nonetheless, they had a desire to communicate with both churches directly. The reformers were interested to see whether reformed theological ideas would fall on sympathetic ears. Badly equipped as they were, the theologians put their lives at risk when they set out for a journey which had the sole purpose of theological exchange. A young theologian from Tübingen was supposed to travel to Ethiopia as a representative of the two leading reformers of the so called second Reformation without any previous knowledge of the language. ${ }^{3}$ He was to travel through the

1 For the sources for the example of David Chytraeus, see: David Benga, David Chytraeus (15301560) als Erforscher und Wiederentdecker der Ostkirchen. Seine Beziehungen zu orthodoxen Theologen, seine Erforschung der Ostkirchen und seine ostkirchlichen Kenntnisse (Ph.D. Dissertation, University of Nürnberg-Erlangen, 2001), 104-111; also accessible online, see URL: https:// www.yumpu.com/de/document/view/4508618/dissertation-david-chytraeus-d-benga/109 (07.05.2019).

2 See Stanislau Paulau, Das andere Christentum. Zurtranskonfessionellen Verflechtungsgeschichte von äthiopischer Orthodoxie und europäischem Protestantismus (Göttingen: Vandenhoeck \& Ruprecht, 2021). DOI: https://doi.org/10.13109/9783666336041.

3 See Martin Tamcke, "Filling gaps in the history of Ethio-European relations in the 18 th century. The Moravians and Ethiopia," in Proceedings of the rgth International Conference of Ethiopian Studies, Warsawa 2015 (forthcoming); Martin Tamcke, "In the direction to Massawa in preEgyptian time," in Proceedings of the 1st International Conference on Eritrean Studies 20-22 July 2016. Vol. 1, ed. Zemenfes Tsighe et al. (Asmara: National Higher Education and Research Institute, 2018), 231-237.

(C) STANISLAU PAULAU AND MARTIN TAMCKE, 2022 | DOI:10.1163/9789004505254_008

This is an open access chapter distributed under the terms of the CC BY-NC-ND 4.o license, Tamcke - 9789004505254 
Sahara Desert dressed as a merchant, picking up Arabic along the way. This plan was doomed to fail from the beginning. It is not of primary importance whether the information accessible to the early Protestants would have allowed them to draw sufficient conclusions about the characteristics of the two churches from abroad. If the early generation missionaries had known about the theological differences from the beginning, there might not have been any real interaction between the churches prior to the 19th century. In that case, the first contact would probably have been similar to many other interactions in the missionary context of the 19th and 2oth century. It would have been marked primarily by a western standard that entailed reforms and progress or, in case of resistance, the founding of their own church. Early Protestant missions, however, had other intentions. After all, the German Protestant churches were still cautious about their involvement in missionary work and occasionally decided against it.

The first German Lutheran missionaries who set foot on foreign soil had been instructed by Orientalists to gather information about the local Orthodox church. It soon transpired that this task was almost impossible to fulfil. Time and time again, missionary Bartholomäus Ziegenbalg tried to follow the demanding instructions given to him. ${ }^{5}$ He travelled far in search of the Orthodox Saint Thomas Christians. ${ }^{6}$ He was posted in the Danish colony Tranquebar, a region in present-day Tamil Nadu. Unfortunately, he discovered that there

4 See Lina Elhage-Mensching, "Wie kommt man nach Äthiopien? Patriarch Markos VII (r. 17451769), Abuna Johannes III. (r. 1747-1761) und Ireneos Hocker (1713-1782)," in Imaginiert und real, erschaut und erdacht. Literarische Werke von und über Christen in Ägypten, ed. Martin Tamcke and Heike Behlmer (Wiesbaden: Harrassowitz, 2017), 79-88.

5 For Ziegenbalg, see: Rekha Kamath Rajan, "Cultural Deliminations. The Letters and Reports of Bartholomäus Ziegenbalg," in Halle and the Beginning of Protestant Christianity in India. Vol. 3, Communication between India and Europe, ed. Andreas Gross, Vincent Kumaradoss and Heike Liebau (Halle:Verlag der Franckeschen Stiftungen zu Halle, 2006), 1221-1239. The instructions for his search came from Johann David Michaelis, see: Brigitte Klosterberg, “'How Many People Can an Elephant Carry?' Questions from Johann David Michaelis to the Missionaries in East India," in Halle and the Beginning of Protestant Christianity in India. Vol. 3, Communication between India and Europe, ed. Andreas Gross, Vincent Kumaradoss and Heike Liebau (Halle: Verlag der Franckeschen Stiftungen zu Halle, 2006), 1091-1114.

6 For a more comprehensive overview, see: Martin Tamcke, "Lutheran Contacts with the Syrian Orthodox of the St. Thomas Christians and with the Syrian Apostolic Church of the East in India (Nestorians)," in Halle and the Beginning of Protestant Christianity in India. Vol. 2, Christian Mission in the Indian Context, ed. Andreas Gross, Vincent Kumaradoss and Heike Liebau (Halle: Verlag der Franckeschen Stiftungen zu Halle, 2006), 831-878. Cf. Martin Tamcke, "Die frühen lutherischen Missionare in ihrem Kontakt zur syrischen Thomaschristenheit," in Ego sum qui sum. Festschrift für Jouko Martikainen, ed. Tuomas Martikainen (Åbo: Åbo Akademi, 2006), $115^{-1} 5^{6 .}$ 
were no Orthodox Saint Thomas Christians living in the area. He had to rely on the information he got from local Catholic Christians. They, in turn, only knew what they were told by the Malabar 'pagans' of Mylapore upon their arrival. ${ }^{7}$ The fact that Syriac was not among the practiced languages of his mission in India was another obstacle. ${ }^{8}$

The next generation had a more systematic approach; they acquired a basic knowledge of Syriac. ${ }^{9}$ As there was still no face-to-face contact, they put their new language skills to use and wrote a letter to the Orthodox representatives in India. They received an answer by the leader of the Orthodox Saint Thomas Christians; the correspondence caused some irritation..$^{10}$ The leader of Indian Orthodoxy was puzzled by the fact that they had sent him a Tamil translation of the Bible-a language he did not understand himself. He wrote his response in Syriac. Thus began both real interaction and an intercultural learning process.

Archiv Franckescher Stiftungen / Archive of Francke Foundations (= AFSt), M 1 C 4: 10a, Letter from Bartholomäus Ziegenbalg and Johann Ernst Gründler to Anton Wilhelm Boehme from Tranquebar on 16.9.1712, edited in excerpts in: Gotthilf August Francken, ed., Achte Continuation des Berichts der Königlichen Dänischen Mißionarien in Ost-Indien, 3rd ed. (Halle: Waysenhaus, 1745), 6o5-614. See also: Arno Lehmann, ed., Alte Briefe aus Indien. Unveröffentlichte Briefe von Bartholomäus Ziegenbalg 1706-1719 (Berlin: Evangelische Verlags-Anstalt, 1957), 241.

8 For Syriac in Halle in general, see: Tamcke, "Lutheran Contacts," 842-846.

9 The first missionary really trained in Syriac was Benjamin Schultze, see: Heike Liebau, Die Sprachforschungen des Missionars Benjamin Schultze unter besonderer Berücksichtigung der "Grammatica Hindostanica." Historisch-linguistische Untersuchungen (Ph.D. Dissertation, University of Halle-Wittenberg, 1989). For the later period, see: Tamcke, "Lutheran Contacts," 86o-864.

10 For this correspondence, see: Martin Tamcke, "Lutheran Contacts with the Syrian Orthodox Church of the St. Thomas Christians and with the Syrian Apostolic Church of the East in India (Nestorians)," Христианство на Ближнем Востоке (Hristianstvo na Blizhnem Vostoke) 1 (2017): 13-49; Martin Tamcke, "The Letters of Bishop Mar Thoma in the Archive of the Francke Foundations in Halle," Hekamtho. Syrian Orthodox TheologicalJournal 1 (2015): 49-58; Martin Tamcke, "Mar Thoma: eine indische Stimme der syrischen Thomaschristenheit in der Interaktion mit deutschen und niederländischen Protestanten," in Veränderte Landkarten. Auf dem Weg zu einer polyzentrischen Geschichte des Weltchristentums (Festschrift für Klaus Koschorke zum 65. Geburtstag), ed. Ciprian Burlacioiu and Adrian Hermann (Wiesbaden: Harrassowitz, 2013), 95-110; Martin Tamcke, "Who is Bishop Gabriel? Essay on the East Syrian opponent of Mar Thoma v," The Harp. A Review of Syriac and Oriental Ecumenical Studies 27 (2011): 211-224; Martin Tamcke, "Der Brief des Mar Thomas V. von 1728 (AFst, M 1 B 1: 11 ab) als Quelle zur Geschichte der syrischen Thomaschristenheit," in Akten des 5. Symposiums zur Sprache, Geschichte, Theologie und Gegenwartslage der syrischen Kirchen, Berlin 14.-15. Juli 2006, ed. Rainer Voigt (Aachen: Shaker, 2010), 251-266; Martin Tamcke, "A letter of Mar Thoma's from 1728 as source for the history of the Syrian St. Thomas Christians," The Harp. A Review of Syriac and Oriental Ecumenical Studies 22 (2007): 201-214. 
At the time, however, Ziegenbalg was only able to report based on third-hand information. His background in systematic theology shows up when he concluded that Indian Christians might have gotten their name as Saint Thomas Christians from the Portuguese in order to avoid communion with Rome. So how should we perceive the Saint Thomas Christians? Did they actually all convert to Catholicism? There were no Saint Thomas Christians left surrounding Santhome, Mylapore. He learned from the Portuguese, however, that they could be found in Cochin at the Malabar Coast and they were now members of the Roman Catholic Church.11

In Madras Ziegenbalg visited an Armenian church service and talked to the priest of the parish. ${ }^{12}$ He had several further encounters with Armenians in India and was received with both understanding and actual help in his search for the Saint Thomas Christians. In a second letter dated 15 November 1713 to Berlin he continued his report from the previous year. ${ }^{13}$ It says: "We have already reported on the Saint Thomas Christians over the past years." ${ }^{14}$ The Portuguese were adamant that these old-established Christians were descendants of Saint Thomas the Apostle. They said that they even referred to an old disciple of the Saint Thomas Christians who had told them about the Gospel of Thomas and shown them the relevant monuments. The actual Saint Thomas Christians were said to have moved to the Malabar Coast back in the day. ${ }^{15}$ In the first half of the 18th century, during the time of the missions, St. Thomas Mount was still a place of pilgrimage for the Saint Thomas Christians. ${ }^{16}$ Ziegenbalg learned more from an Armenian account. Supposedly, the book was "written before the Portuguese arrived in East India and written in Armenian."17 Thomas is said to have travelled to India and stayed in Mylapore. There were numerous books about it in Indian Christian tradition. But they were "all written after," meaning

\footnotetext{
11 See AFSt, M 1 C 4: 10a; Lehmann, Alte Briefe, 242.

12 See AFSt, M $1 C_{3}$ : 1, Letter of Heinrich Plütschau, Johann Ernst Gründler, Johann Georg Bövingh to August Hermann Francke vom 6.2.1710 from Tranquebar, in: Gotthilf August Francken, ed., Zweyte Continuation des Berichts der Königlichen Dänischen Mißionarien in Ost-Indien, 3rd ed. (Halle: Waysenhaus, 1718), 102-109.

13 See AFSt, M $1 C_{5}$ : 75/1-13 (ALMW/DHM 10/21: 5o, transcript of the preceding letter), Letter of Bartholomäus Ziegenbalg and Johann Ernst Gründler to the dear fathers and men in God in Berlin vom 15.11.1713 from Tranquebar, in: Lehmann, Alte Briefe, 345-356.

14 AFSt, M 1 C 5: 75/1-13 (ALMw/DHM 10/21: 5o); Lehmann, Alte Briefe, 349.

15 Cf. the explanation by Folker Reichert on his edition of the report by Oderich of Pordenone: Folker Reichert, trans. and ed., Die Reisen des seligen Odorich von Pordenone nach Indien und China (1314/18-1330) (Heidelberg: Manutius, 1987).

16 See Wilhelm Germann, Die Kirche der Thomaschristen. Ein Beitrag zur Geschichte der Orientalischen Kirchen (Gütersloh: Bertelsmann, 1877), 559 . Ibid.
} 
after the arrival of the Portuguese. ${ }^{18}$ Also they "included many fables."19 Still, Ziegenbalg received the same answer wherever he went, "Saint Thomas the Apostel himself had been in India." ${ }^{20}$ In order to verify these claims he would have to travel to the Malabar Coast. The picture becomes more complex, when reports declare that these Christians were not actually Saint Thomas's progeny, but those of a Syrian whose name-Mar Thoma-was responsible for their designation. ${ }^{21}$ This Syrian was said to have arrived in India as late as the $5^{\text {th }}$ century. From this time onwards until the arrival of the Portuguese there had only been bishops from Syria who had used Syriac in their church services. ${ }^{22}$

A journey to Kerala was impossible for Ziegenbalg and Heinrich Plütschau. ${ }^{23}$ So they sought contact through writing instead. Ziegenbalg's main interest was concerned with doctrinal theology. He was suspicious of their attempts at entering communion with the Catholic Church. The Roman Church was very eager to "lead these Thomas Christians to the Holy See," but the old-established Christians never voluntarily followed. ${ }^{24}$ Contrary to the reports he received about a union of these Thomas Christians with Rome, Ziegenbalg remained convinced that he would find in them fellow sufferers, who struggled under the Roman dominance like the Protestants.

At first, the "papists" had tried to convince the Saint Thomas Christians with kindness and promises. ${ }^{25}$ But they defied these efforts and declared that they were "not interested in any Pope or alien doctrines." ${ }^{26}$ As soon as the Portuguese had established their position in India, the attempts at joining these Christians with the Roman Catholic Church intensified and became violent. The bishop

18 AFSt, M 1 C 5: 75/1-13.

19 Ibid.

20 Ibid.

21 See Tamcke, "Lutheran Contacts," 835-836; Lehmann, Alte Briefe, 349-350.

22 See AFSt, M 1 C 5: 75/1-13 (ALmw/Dhm 10/21: 50); Lehmann, Alte Briefe, 349-350. It is very likely that the Syrian in Ziegenbalg's report refers to the merchant Thomas of Cana, although this is difficult to verify. Tradition places him in the year 345 when he and 72 other families came to Cranganore and settled there. The only discrepancy lies in Ziegenbalg's time frame which places his arrival in the fifth century. On the union of the Syrians with Rome see: Joseph Thekkedath, History of Christianity in India. Vol. 2, From the Middle of the Sixteenth to the End of the Seventeenth Century (1542-1700) (Bangalore: Church History Association of India, 1988).

23 For Plütschau, see: Martin Tamcke, "Heinrich Plütschau. The Man in Ziegenbalg's Shadow," in Halle and the Beginning of Protestant Christianity in India. Vol. 1, The Danish-Halle and English-Halle-Mission, ed. Andreas Gross, Vincent Kumaradoss and Heike Liebau (Halle: Verlag der Franckeschen Stiftungen zu Halle, 2006), 547-566.

24 Lehmann, Alte Briefe, 35o.

25 Ibid.

26 AFSt, M 1 C 5: 75/1-13 (ALmw/DHM 10/21: 50); Lehmann, Alte Briefe, 350. 
was captured and the Catholic doctrine was forced upon the people. Ziegenbalg knew about later efforts to re-establish contact between the Syrian Church and India. Syrian bishops had tried to come to India, but they were hindered by the Portuguese. He felt the suffering such disputes caused among the Christians. Among his documents were reports from a Syrian bishop of the Saint Thomas Christians who was imprisoned in Pondicherry at the time. Many Saint Thomas Christians sought protection with the Dutch in order to escape the yoke under the Portuguese. The Dutch were not affiliated with Rome. Other members of the Saint Thomas Christians who did not join the Roman Catholic Church were located in the middle of the country. ${ }^{27}$ After the end of Portuguese hegemony, they took advantage of the "pagan rulers" and returned to following their traditional doctrines. ${ }^{28}$

Initially Ziegenbalg assumed that all Saint Thomas Christians in Kerala had entered communion with Rome, only to later learn of the schism among the Thomas Christians. ${ }^{29}$ He thought the schism was a consequence of political alterations following the change in colonial leadership from the Portuguese to the Dutch. It was the protection by the Dutch that made communications with Rome possible again. There is no indication of him knowing the differentiation the Dutch made between the different groups of Thomas Christians in Kerala. He does not mention that the Dutch fancied themselves protectors of those Saint Thomas Christians who were in communion with Rome.

It is recorded in Indian church history after the Synod of Diamper (2028 June 1599) that the Portuguese kept Syrian bishops from entering India. ${ }^{30}$ Bishop Ahathalla's actions since $165^{2}$ pushed the Syrians, who were eager to be independent, in the direction of the miaphysites. ${ }^{31}$ The Koonan Kurishu (Coonan Cross) oath on 3 January 1653 was the final chapter of reparations to the Saint Thomas Christians and a clarion call for the independence of the Syrians in India from Rome. ${ }^{32}$

27 Ibid., 349-35o; Tamcke, "Lutheran Contacts," 836.

28 Lehmann, Alte Briefe, 35o; Tamcke "Lutheran Contacts," 837.

29 Ibid., 837-841.

$30 \quad$ On the discussion about this Synod, see: Karen Hermes, "Countdown to 1999. Die Synode von Diamper (1599) im Spiegel der verschiedenen Kirchen der südindischen Thomaschristenheit," in Syrisches Christentum weltweit. Studien zur syrischen Kirchengeschichte (Festschrift Prof. Wolfgang Hage), ed. Martin Tamcke (Münster: Lit, 1995), 325-340.

31 See Stephen Neill, A History of Christianity in India. Vol. 1, The Beginnings to AD 1707 (Cambridge: Cambridge University Press, 1985), 316-319; Thekkedath, "History of Christianity," 91-94; Edouard Hambye and Johannes Madey, 19oo Jahre Thomas-Christen in Indien (Fribourg: Kanisius-Verlag, 1972), 35.

32 How the respective denominational position of each church historian nowadays affects their interpretations of events can be exemplified by the following analysis of the synod 
It is obvious that the Portuguese influence on the church-internal affairs of the Saint Thomas Christians was not Ziegenbalg's only concern. Otherwise, why would he be referring to this particular bishop in the context of Portuguese interference? Pondicherry is not Portuguese but French territory after all. It seems he was more concerned with the access from any Catholic leadership in favour of the Catholic Church and at the expense of the independent Saint Thomas Christians. The political argument is included in the denominational polemics. He could also connect it to crucial developments in the church history. Ziegenbalg brought his preconceived notions to all his efforts and they merely needed proof: The Syrian Saint Thomas Christians sought to assert themselves just as the Protestants did in Europe and both had Roman Catholicism as their opponent. They each fought for independence which also explains why the German Lutherans were eager to establish contact with these potential fellow-sufferers to take defensive action against Roman influence.

Christoph Theodosius Walther, a missionary who followed Ziegenbalg in his efforts to establish a connection to the Saint Thomas Christians, highlighted in his reports how the Syrian Christians resisted Rome. His commitment to the Saint Thomas Christians was based upon this resistance, which gave him a strong strategic argument for his mission. This is where Ethiopia comes in. Walther compared the consequences of Portuguese rule and their connection to the Jesuits in India to the Portuguese and Jesuits in Ethiopia. Syrian Christians of the Malabar Coast did not bow to the pope's will and neither did Christians in Ethiopia. In both regions the Catholics' endeavours were fruitless. The parallel Walther draws between the historical background of the Orthodox Ethiopians and Indians is based on one crucial point: Both Orthodox communities withstood the pull of Rome. The conflict with Rome actually brought their denominational differences to light. It is the steadfastness of the Ethiopians and the Indians that raised hope in the Lutheran missionaries from Germany.

Comparing the two countries and their struggles with Rome, Walther would see a staging of the same ostensible comedy - be it by different people. ${ }^{33}$ The Jesuit and Archbishop Alexis (Aleixo) de Menezes ${ }^{34}$ as well as the Jesuit Patriarch Alphons Mendez ${ }^{35}$ in Ethiopia had pointed out the fallacies of the Indian

of Diamper: Hermes, "Countdown." Thus far there has not been an interpretation which considers only the facts and disregards the author's position.

34 See Pius Malekandathil, ed., Jornada of Dom Alexis des Menezes. A Portuguese Account of the Sixteenth Century Malabar (Kochi: LRC Publ., 2003).

35 Here the way to Ethiopia already crosses the way to India, when Hieronymus Lobos on his way to Ethiopia met Alphons Mendez, the patriarch of Ethiopia, see: Theophil Friedrich 
Christians and demanded they submit to the Roman rule. The former railed against Nestorius and the latter against Dioscorus. In both cases the Catholic Church operated from the standpoint of Catholic orthodoxy and identified their Ethiopian and Indian counterparts as heretics. Both representatives of the Jesuits under Portuguese rule were accused of rebaptism by Walther. They had introduced Iconodulism, which was supposedly unacceptable in both Ethiopia and India. This claim seems rather contrary to the culture of images in both communities. What could have led Walther to this conclusion is a matter of further examination. The domineering nature of the Portuguese would have led to rebellion in any case. Under no circumstances would the Portuguese have lost sight of their objective to seize power in both countries. They bewitched the allegedly unsuspecting people with splendid churches. The Syriac Bible was altered according to the Vulgate just like the new Amharic Bible was created. But later they also had prevented the arrival of an Alexandrian metropolitan to Ethiopia and prevented a Babylonian metropolitan from coming to India.

The similarities between the situations in Ethiopia and India gave Walther the idea that the community in India could benefit from the Ethiopian example and the acting Protestant missionary Peter Heyling. ${ }^{36}$ If he could prove that a Lutheran was helpful in gaining ecclesiastical independence, this would support his argument for a tripartite alliance between the Lutherans, Ethiopians, and Indians. He used his contacts to well-travelled Armenians to get a written account of Heyling's life. Walther arranged for the Armenian merchant Peter Nuri from Persia to write down a report by the Armenian Morad about the end of Heyling's life. ${ }^{37}$ At the same time, he asked the merchant to look out

Ehrmann, trans. and ed., P. Hieronymus Lobo's, eines portugiesischen Jesuiten, Reise nach Habessinien, und zu den Quellen des Nils. Vol. 1 (Zürich: Orell, 1793), 90-96.

36 See Johann Heinrich Michaelis, Sonderbarer Lebenslauf Herrn Peter Heylings, und dessen Reise nach Ethiopien, nebst zugänglichen Berichten von der im selbigen Reiche zu Anfang des XVII Saeculi entstandenen Religions-Unruhe (Halle: Waysenhaus, 1724). Johann Heinrich Michaelis is the uncle of Christian Benedikt Michaelis, who took him in his home in Halle and gave him the instruction for the oriental languages. He is the father of Johann David Michaelis, who was teaching in Göttingen since 1745. In their correspondence with the missionaries in India they asked for information about the Thomas Christians and their history. For Heyling, see also: Manfred Kropp, "Ein äthiopischer Text zu Peter Heyling. Ein bisher unbeachtetes Fragment einer Chronik des Fasiladas," in Proceedings of the Seventh International Conference of Ethiopian Studies, University of Lund, 26-29 April 1982, ed. Sven Rubenson (Addis Abeba: Institute of Ethiopian Studies, 1984), 243-252.

37 In general on the contact of the Lutherans with the Armenians in India, see: Martin Tamcke, "Early Protestant Missionaries and their Contacts with the Armenians," in Halle and the Beginning of Protestant Christianity in India. Vol. 2, Christian Mission in the Indian 
for any other reports on Heyling all around the world and send it to Madras. Walther was not very optimistic though, given that there was not even information to be found at the Ethiopian court. Walther commissioned an extract on Heyling's life and a report on the riots in Ethiopia that led to the expulsion of the Jesuits and the Portuguese. Through the Ethiopian and Indian example, the rural Indian catechists could observe how the Catholics' attempts to subdue other countries came to nothing. And they could see that both countries used the same pretence to achieve their goal.

The fact that Ethiopia had already thrown off the Portuguese-Catholic yoke, while only a part of the Syrian Christians in India had gained back their independence is utilised as an implicit advice in a pedagogy of liberation. The Ethiopians and their history are turned into an encouraging example that is to be followed in a fight for freedom. The Lutherans hence presented themselves as allies in the defence against Rome. ${ }^{38}$

Walther instructed the rural catechists to make the Indians aware of this historical example. He meant to ensure that no external influences could alter the Indian or Ethiopian context. It was supposed to strengthen their selfhood. Ethiopia had become a paragon for the Indian Saint Thomas Christians and their fight for independence, but also for those Indians who had only recently found their way to Christianity and joined the Lutheran mission in Tranquebar.

Context, ed. Andreas Gross, Vincent Kumaradoss and Heike Liebau (Halle: Verlag der Franckeschen Stiftungen zu Halle, 2006), 813-830; with small revisions: Martin Tamcke, "Die Präsenz und Rolle der Armenier unter den indischen Christen," in Bibel, Byzanz und Christlicher Orient (Festschrift für Stephen Gerö zum 65. Geburtstag), ed. Dmitrij Bumazhnov (Leuven: Peeters, 2011), 465-485; Martin Tamcke, "Lutheran-Armenian Contacts in India 1708-1765," Chronos, Revue d'Histoire de l'Université de Balamand 16 (2007): 129148. Cf. also: Martin Tamcke, "Konstruktionen lutherisch-syrischer Gemeinsamkeiten in der Frühphase lutherischer Mission in Indien," in Construction of the Other, Identification of the Self. German Mission in India, ed. Martin Tamcke and Gladson Jathanna (Wien: Lit, 2012), 1-12. For a synthetic text of the letters of Mar Thoma, see: Martin Tamcke, "Mar Thoma to Mr. Carolus," in Halle and the Beginning of Protestant Christianity in India. Vol. 3, Communication between India and Europe, ed. Andreas Gross, Vincent Kumaradoss and Heike Liebau (Halle: Verlag der Franckeschen Stiftungen zu Halle, 20o6), 13791382 .

38 Later they clearly refused any idea of unification of the Thomas Christians with the Protestants (they meant here only the Lutherans and were clearly rivals of the Dutch Reformed), see: Germann, Die Kirche der Thomaschristen, ${ }_{5}^{61}$ ("Die Missionare halten dafür, daß an eine Vereinigung mit den Protestanten gar nicht zu denken wäre”). 


\section{List of References}

AFSt $=$ Archiv Franckescher Stiftungen (Archive of Francke Foundations).

Benga, David. David Chytraeus (1530-1560) als Erforscher und Wiederentdecker der Ostkirchen. Seine Beziehungen zu orthodoxen Theologen, seine Erforschung der Ostkirchen und seine ostkirchlichen Kenntnisse. Ph.D. Dissertation, University of NürnbergErlangen, 2001.

Ehrmann, Theophil Friedrich, trans. and ed. P. Hieronymus Lobo's, eines portugiesischen Jesuiten, Reise nach Habessinien, und zu den Quellen des Nils. Vol. 1. Zürich: Orell, 1793. Elhage-Mensching, Lina. "Wie kommt man nach Äthiopien? Patriarch Markos VII (r. 1745-1769), Abuna Johannes III. (r. 1747-1761) und Ireneos Hocker (1713-1782)." In Imaginiert und real, erschaut und erdacht. Literarische Werke von und über Christen in Ägypten, edited by Martin Tamcke and Heike Behlmer, 79-88. Wiesbaden: Harrassowitz, 2017 .

Francken, Gotthilf August, ed. Achte Continuation des Berichts der Königlichen Dänischen Mißionarien in Ost-Indien. 3rd ed. Halle: Waysenhaus, 1745.

Francken, Gotthilf August, ed. Zweyte Continuation des Berichts der Königlichen Dänischen Mißionarien in Ost-Indien. 3rd ed. Halle: Waysenhaus, 1718.

Germann, Wilhelm. Die Kirche der Thomaschristen. Ein Beitrag zur Geschichte der Orientalischen Kirchen. Gütersloh: Bertelsmann, 1877.

Hambye, Edouard and Johannes Madey. 19ooJahre Thomas-Christen in Indien. Fribourg: Kanisius-Verlag, 1972.

Hermes, Karen. “Countdown to 1999. Die Synode von Diamper (1599) im Spiegel der verschiedenen Kirchen der südindischen Thomaschristenheit." In Syrisches Christentum weltweit. Studien zur syrischen Kirchengeschichte (Festschrift Prof. Wolfgang Hage), edited by Martin Tamcke, 325-340. Münster: Lit, 1995.

Klosterberg, Brigitte. “'How Many People Can an Elephant Carry?' Questions from Johann David Michaelis to the Missionaries in East India." In Halle and the Beginning of Protestant Christianity in India. Vol. 3, Communication between India and Europe, edited by Andreas Gross, Vincent Kumaradoss and Heike Liebau, 1091-1114. Halle: Verlag der Franckeschen Stiftungen zu Halle, 2006.

Kropp, Manfred. "Ein äthiopischer Text zu Peter Heyling. Ein bisher unbeachtetes Fragment einer Chronik des Fasiladas." In Proceedings of the Seventh International Conference of Ethiopian Studies, University of Lund, 26-29 April 1982, edited by Sven Rubenson, 243-252. Addis Abeba: Institute of Ethiopian Studies, 1984.

Lehmann, Arno, ed. Alte Briefe aus Indien. Unveröffentlichte Briefe von Bartholomäus Ziegenbalg 1706-1719. Berlin: Evangelische Verlags-Anstalt, 1957.

Liebau, Heike. Die Sprachforschungen des Missionars Benjamin Schultze unter besonderer Berücksichtigung der "Grammatica Hindostanica." Historisch-linguistische Untersuchungen. Ph.D. Dissertation, University of Halle-Wittenberg, 1989. 
Malekandathil, Pius, ed. Jornada of Dom Alexis des Menezes. A Portuguese Account of the Sixteenth Century Malabar. Kochi: LRC Publ., 2003.

Michaelis, Johann Heinrich. Sonderbarer Lebenslauf Herrn Peter Heylings, und dessen Reise nach Ethiopien, nebst zugänglichen Berichten von der im selbigen Reiche zu Anfang des XVII Saeculi entstandenen Religions-Unruhe. Halle: Waysenhaus, 1724.

Neill, Stephen. A History of Christianity in India. Vol. 1, The Beginnings to AD 1707. Cambridge: Cambridge University Press, 1985.

Paulau, Stanislau. Das andere Christentum. Zur transkonfessionellen Verflechtungsgeschichte von äthiopischer Orthodoxie und europäischem Protestantismus. Göttingen: Vandenhoeck \& Ruprecht, 2021. DoI: https://doi.org/10.13109/9783666336041.

Rajan, Rekha Kamath. "Cultural Deliminations. The Letters and Reports of Bartholomäus Ziegenbalg." In Halle and the Beginning of Protestant Christianity in India. Vol. 3, Communication between India and Europe, edited by Andreas Gross, Vincent Kumaradoss and Heike Liebau, 1221-1239. Halle: Verlag der Franckeschen Stiftungen zu Halle, 2006.

Reichert, Folker, trans. and ed. Die Reisen des seligen Odorich von Pordenone nach Indien und China (1314/18-1330). Heidelberg: Manutius, 1987.

Tamcke, Martin. "A letter of Mar Thoma's from 1728 as source for the history of the Syrian St. Thomas Christians." The Harp. A Review of Syriac and Oriental Ecumenical Studies 22 (2007): 201-214.

Tamcke, Martin. "Der Brief des Mar Thomas V. von 1728 (AFst/M 1 B 1: 11 ab) als Quelle zur Geschichte der syrischen Thomaschristenheit." In Akten des 5. Symposiums zur Sprache, Geschichte, Theologie und Gegenwartslage der syrischen Kirchen, Berlin 14.15. Juli 2006, edited by Rainer Voigt, 251-266. Aachen: Shaker, 2010.

Tamcke, Martin. "Die frühen lutherischen Missionare in ihrem Kontakt zur syrischen Thomaschristenheit." In Ego sum qui sum. Festschrift für Jouko Martikainen, edited by Tuomas Martikainen, 115-156. Åbo: Åbo Akademi, 2006.

Tamcke, Martin. "Early Protestant Missionaries and their Contacts with the Armenians." In Halle and the Beginning of Protestant Christianity in India. Vol. 2, Christian Mission in the Indian Context, ed. Andreas Gross, Vincent Kumaradoss and Heike Liebau, 813-83o. Halle: Verlag der Franckeschen Stiftungen zu Halle, 2006.

Tamcke, Martin. "Filling gaps in the history of Ethio-European relations in the 18th century. The Moravians and Ethiopia." In Proceedings of the 19th International Conference of Ethiopian Studies, Warsawa 2015. Forthcoming.

Tamcke, Martin. "Heinrich Plütschau. The Man in Ziegenbalg's Shadow." In Halle and the Beginning of Protestant Christianity in India. Vol. 1, The Danish-Halle and EnglishHalle-Mission, edited by Andreas Gross, Vincent Kumaradoss and Heike Liebau, 547-566. Halle: Verlag der Franckeschen Stiftungen zu Halle, 2006.

Tamcke, Martin. "In the direction to Massawa in pre-Egyptian time." In Proceedings of the 1st International Conference on Eritrean Studies 20-22 July 2016. Vol. 1, edited by 
Zemenfes Tsighe et al., 231-237. Asmara: National Higher Education and Research Institute, 2018.

Tamcke, Martin. "Konstruktionen lutherisch-syrischer Gemeinsamkeiten in der Frühphase lutherischer Mission in Indien." In Construction of the Other, Identification of the Self. German Mission in India, edited by Martin Tamcke and Gladson Jathanna, 1-12. Wien: Lit, 2012.

Tamcke, Martin. "Lutheran Contacts with the Syrian Orthodox Church of the St. Thomas Christians and with the Syrian Apostolic Church of the East in India (Nestorians)." Христианство на Ближнем Востоке (Hristianstvo na Blizhnem Vostoke) 1 (2017): 13-49.

Tamcke, Martin. "Lutheran Contacts with the Syrian Orthodox of the St. Thomas Christians and with the Syrian Apostolic Church of the East in India (Nestorians)." In Halle and the Beginning of Protestant Christianity in India. Vol. 2, Christian Mission in the Indian Context, edited by Andreas Gross, Vincent Kumaradoss and Heike Liebau, 831-878. Halle: Verlag der Franckeschen Stiftungen zu Halle, 2006.

Tamcke, Martin. "Lutheran-Armenian Contacts in India 1708-1765." Chronos, Revue d'Histoire de l'Université de Balamand 16 (2007): 129-148.

Tamcke, Martin. "Mar Thoma to Mr. Carolus." In Halle and the Beginning of Protestant Christianity in India. Vol. 3, Communication between India and Europe, ed. Andreas Gross, Vincent Kumaradoss and Heike Liebau, 1379-1382. Halle: Verlag der Franckeschen Stiftungen zu Halle, 2006.

Tamcke, Martin. "Mar Thoma: eine indische Stimme der syrischen Thomaschristenheit in der Interaktion mit deutschen und niederländischen Protestanten." In Veränderte Landkarten. Auf dem Weg zu einer polyzentrischen Geschichte des Weltchristentums (Festschrift für Klaus Koschorke zum 65. Geburtstag), edited by Ciprian Burlacioiu and Adrian Hermann, 95-110. Wiesbaden: Harrassowitz, 2013.

Tamcke, Martin. "The Letters of Bishop MarThoma in the Archive of the Francke Foundations in Halle." Hekamtho. Syrian Orthodox Theological Journal 1 (2015): 49-58.

Tamcke, Martin. "Who is Bishop Gabriel? Essay on the East Syrian opponent of Mar Thoma V." The Harp. A Review of Syriac and Oriental Ecumenical Studies 27 (2011): 211-224.

Tamcke, Martin. "Die Präsenz und Rolle der Armenier unter den indischen Christen." In Bibel, Byzanz und Christlicher Orient (Festschrift für Stephen Gerö zum 65. Geburtstag), edited by Dmitrij Bumazhnov, 465-485. Leuven: Peeters, 2011.

Thekkedath, Joseph. History of Christianity in India. Vol. 2, From the Middle of the Sixteenth to the End of the Seventeenth Century (1542-1700) (Bangalore: Church History Association of India, 1988). 